\title{
Meat yield characteristics of three genotypes of ducks in coastal region of Bangladesh
}

\author{
MA I slam, MJ Khan, MR Debi* , MM Rahman
}

Department of Animal Nutrition, Bangladesh Agricultural University, Mymensingh-2202, Bangladesh

\begin{abstract}
A study was conducted to determine the meat yield characteristics of Khaki Campbell, Jinding and Deshi duck in two coastal locations of Barisal and Bhola districts of Bangladesh. Sixty day-old ducklings of three genotypes of duck were randomly allocated to 3 treatments having 4 replications in each genotype. Ducklings are reared up to 150 days and at the end of experiment, one male duck of highest live weight was selected from each replication in the morning before feeding and dissected to determine the meat yield characteristics. Significant $(p<0.01)$ differences were found between different genotypes in carcass weight and dressed weight of ducks. Significant $(p<0.01)$ differences were also observed for weight of breast, thigh, leg, shank and drumstick weight as well as dressing percentage. Dressed weight and dressing percentage in Khaki Campbell was significantly $(p<0.01)$ higher than that of the Jinding and Deshi genotypes. Considering the parameters studied both Khaki Campbell and Jinding ducks may be suggested to rear in the coastal region of Bangladesh.
\end{abstract}

Key words: Duckling, genotype, growth, coastal region

Bangladesh Animal Husbandry Association. All rights reserved.

Bang. J. Anim. Sci. 2012. 41 (2): 79-82

\section{I ntroduction}

Duck rearing is an integral part of poultry husbandry. Poultry meat and egg play an important role in human nutrition throughout the world. Poultry meat contributes approximately $30 \%$ of the total animal protein and during last 10 years this proportion has increased from 20 to $30 \%$ of all animal protein and is thought to increase to $40 \%$ before 2015 . Duck population of Bangladesh is estimated to be $\mathbf{3 5 . 5 3}$ million (DLS, 2003) of which $95 \%$ are of indigenous type. The climate and environment of Bangladesh are suitable for duck habitation and her innumerable water bodies are also favorable for duck production. Duck production plays an important role in the southern coastal districts of Bangladesh, providing meat and egg in the diets of the people and income from local sale and in the market. Naturally, Bangladesh is a riverine country and $16488 \mathrm{Km}^{2}$ of its total area are haors, canals, pond and low-lying water reservoir, most of them can be efficiently utilized for duck production. In Bangladesh 95 percent of total duck population are indigenous (Ahmed and Islam 1985 and Arboleda 1990). Genotypes of ducks available in the country are Khaki Campbell, Indian Runner, J inding, Pekin and their crosses. Local ducks are ubiquitous in the country and most smallholder farmers keep them under subsistence level of management.
Duck meat and eggs are thus the cheapest protein food among animal protein sources available in Bangladesh. Ducks have a great role in village poultry production (Farrell and Stapleton, 1986). About $89 \%$ of rural livestock households rear poultry (Islam et al. 2003). Consumption of duck meat and eggs in the country is estimated about 30 percent of total poultry meat and egg consumption (I slam et al. 2003). In coastal region of Barisal and Bhola peoples are rearing indigenous non-descriptive ducks from ancient time. Now a day in parallel to Deshi, Jinding and Khaki Campbell ducks are getting popularity to the farmers of these areas. But no comparative study on productivity, acclimatization ability and meat yield characteristics on local birds were done in coastal environments. Therefore, the present study was conducted in two southern districts (Barisal and Bhola) of Bangladesh to know the quality characteristics of meat of three genotypes of ducklings (Khaki Campbell, Jinding and Deshi) in the coastal region.

\section{Materials and Methods}

The experiment was conducted with a total of 60 day old ducklings (having 48 ducklings in each district) of Desi, Jinding and Khaki Campbell for a period of three months in southern two coastal districts, Barishal and Bhola to study the meat 
yield charecteristics of scavenging ducklings with supplementary feeding. In order to select farmers for the study, socioeconomic conditions of the rearer and their previous experience on duck rearing was collected from the NGOs, BDS for Barisal and COAST for Bhola. Twelve farmers were selected in each districts based on their previous experience on duck rearing. The experiment was conducted following Completely Randomized Design (CRD). All birds in each location were randomly divided into three treatment groups according to genotype. The number of observation per treatment was 16 birds. Each genotype was considered as one treatment. Each of the treatment groups was subjected to four replications and number of observations per replication was 4 birds.

Supplemental feeds were supplied in the form of concentrate mixture composed of broken rice @30\%, crushed maize @ 30\% rice polish @25\% and wheat bran @15\%. All the feed ingredients were purchased from local feed shop of Barisal and Bhola. In addition to scavenging, each duckling was supplied with $40 \mathrm{~g}$ feed from 2 to 3 months, $50 \mathrm{~g}$ from 3 to 4 months and $60 \mathrm{~g}$ from 4 to 5 months of age. The feeds were divided into two equal portions and supplied in the morning at 8.00 am before scavenging and $17.00 \mathrm{pm}$ after returning home from the outside. Body weight of individual bird was measured at the end of each week during the experimental period of 150 days. Mortality of the birds, if any, was recorded group wise. All ducklings were vaccinated against duck plague and duck cholera as per the following schedule.

At the end of experiment one male duck of highest live weight from each of the genotype in two locations was selected and were individually weighed, slaughtered following halal method by severing the jugular (Singh et al. 2003). After complete bleeding, the slaughtered birds were weighed individually, plucked, eviscerated and then dissected to get the weight of different cuts and organs. The different body parts such as shank, head, thigh, leg, wing, neck, dressed carcass, drumstick and abdominal fat were removed after slaughtering of the birds and weight was taken and transformed into percentages of their respective weights. Dressing percentage of individual bird was calculated using the following formula:

Dressing Percentage $=\frac{\text { Dressed weight of bird }}{\text { Live weight of bird }} \times 100$

\section{Statistical analysis}

Data were subjected to analysis of variance in accordance with the procedure of Completely Randomized Design (CRD). Significant differences were identified by Ducan's New Multiple Range Test (DMRT). Mortality occurred in different treatment groups were analyzed by Chi- square test. All analysis were performed by using a MSTAT-C statistical package program using a microcomputer.

\section{Results and Discussion}

The meat yield characteristics of ducks of three genoytpes are presented in Table 1, 2 and 3 . The results showed that there were significant $(p<0.01)$ differences observed among the different genotypes of ducks in terms of carcass weights and dressed weights. In case of Barisal region (Table 1 ), significant $(p<0.01)$ differences were observed for live weight, weight of breast, thigh, leg, shank and drumstick weight abdominal fat, dressed weight and dressing percentage among the three genotypes of duck. There also significant $(p<0.05)$ difference were found in wing weight. In case of head and neck weight, there was no observed any significant difference.

In case of Bhola region (Table 2 ), there were observed significant $(p<0.01)$ difference for all carcass characteristics and dressing percenttage except in neck weight between the three genotypes of duck. The highest average live weight $(1522.50 \mathrm{~g})$ was observed in Khaki Campbell and lowest (1155.83 g) in Deshi. Weight of breast, thigh, head, wing, leg, shank and drumstick in Khaki Campbell and Jinding were significantly $(p<0.01)$ higher than that of the Deshi genotypic of ducks. There were no significant differences among the different genotypes in terms of neck weight. The higher breast weight were found in Jinding (18.75 g/100 gBW) in Barishal. However, the average breast meat yield in Khaki Campbell was $18.76 \mathrm{~g} / 100$ gBW. The difference of breast meat weight between different groups may be due to the genetic potentiality of the genotypes. Mean values for weight of body parts and organs as a proportion of live weight $(\mathrm{g} / 100 \mathrm{gLW})$ of ducklings are given in Table 1 and 2 . The mean values for breast, thigh, head, leg, shank, wing, and drumstick weight as a proportion of live weight $(g / 100 \mathrm{gLW})$ were significantly $(p<0.01)$ higher for Khaki Campbell than that of Jinding and Deshi genotypes. 


\section{Meat potentialities of ducks}

Table 1. Carcass characteristics and dressing percentage of three genotypes of duck at 150 days of age reared in coastal region of Baishal

\begin{tabular}{lcccc}
\hline \multirow{2}{*}{ Parameters } & \multicolumn{4}{c}{ Barisal } \\
\cline { 2 - 5 } & Khaki Campbell & Jinding & Deshi & Level of sig \\
\hline Live weight at slaughter (g) & $1521.67^{\mathrm{a}}$ & $1448.33^{\mathrm{b}}$ & $1148.3^{\mathrm{b}}$ & $* *$ \\
Breast weight (\%) & $18.67^{\mathrm{a}}$ & $18.75^{\mathrm{a}}$ & $17.76^{\mathrm{b}}$ & $* *$ \\
Thigh weight (\%) & $11.35^{\mathrm{a}}$ & $11.35^{\mathrm{a}}$ & $10.25^{\mathrm{b}}$ & $* *$ \\
Head weight (\%) & 3.38 & 3.31 & 3.26 & $\mathrm{NS}$ \\
Neck weight (\%) & 4.84 & 4.78 & 4.73 & $\mathrm{NS}$ \\
Wing weight (\%) & $3.90^{\mathrm{a}}$ & $3.84^{\mathrm{ab}}$ & $3.73^{\mathrm{b}}$ & $*$ \\
Leg weight (\%) & $2.15^{\mathrm{a}}$ & $2.10^{\mathrm{ab}}$ & $2.04^{\mathrm{b}}$ & $* *$ \\
Shank weight (\%) & $2.27^{\mathrm{a}}$ & $2.25^{\mathrm{ab}}$ & $2.11^{\mathrm{b}}$ & $* *$ \\
Drumstick weight (\%) & $12.77^{\mathrm{a}}$ & $11.77^{\mathrm{b}}$ & $12.63^{\mathrm{a}}$ & $* *$ \\
Abdominal fat (\%) & $0.81^{\mathrm{a}}$ & $0.81^{\mathrm{a}}$ & $0.57^{\mathrm{b}}$ & $* *$ \\
Dressed weight (g) & $917.33^{\mathrm{a}}$ & $847.33^{\mathrm{b}}$ & $667.6^{\mathrm{b}}$ & $* *$ \\
Dressing Percentage & $60.14^{\mathrm{a}}$ & $58.95^{\mathrm{ab}}$ & $57.07^{\mathrm{b}}$ & $* *$ \\
\hline abc & &
\end{tabular}

Table 2. Carcass characteristics and dressing percentage of three genotypes of duck at 150 days of age reared in coastal region of Bhola

\begin{tabular}{|c|c|c|c|c|}
\hline \multirow{2}{*}{ Parameters } & \multicolumn{4}{|l|}{ Bhola } \\
\hline & Khaki Campbell & J inding & Deshi & Level of sig \\
\hline Live weight at slaughter $(\mathrm{g})$ & $1523.3^{a}$ & $1435^{\mathrm{ab}}$ & $1163.3^{b}$ & $* *$ \\
\hline Breast weight (\%) & $18.82^{\mathrm{a}}$ & $18.48^{a}$ & $17.77^{\mathrm{b}}$ & $* *$ \\
\hline Thigh weight (\%) & $11.35^{\mathrm{a}}$ & $11.31^{\mathrm{a}}$ & $10.25^{b}$ & $* *$ \\
\hline Head weight (\%) & $3.36^{\mathrm{a}}$ & $3.28^{b}$ & $3.29^{b}$ & $* *$ \\
\hline Neck weight (\%) & 4.79 & 4.74 & 4.78 & NS \\
\hline Wing weight (\%) & $3.86^{\mathrm{a}}$ & $3.82^{\mathrm{ab}}$ & $3.79^{b}$ & $* *$ \\
\hline Leg weight (\%) & $2.15^{\mathrm{a}}$ & $2.09^{\mathrm{ab}}$ & $2.03^{b}$ & $* *$ \\
\hline Shank weight (\%) & $2.25^{\mathrm{a}}$ & $2.24^{\mathrm{a}}$ & $2.16^{\mathrm{b}}$ & $* *$ \\
\hline Drumstick weight (\%) & $12.74^{\mathrm{a}}$ & $11.76^{\mathrm{a}}$ & $12.67^{b}$ & $* *$ \\
\hline Abdominal fat (\%) & $0.81^{a}$ & $0.76^{\mathrm{ab}}$ & $0.62^{b}$ & $* *$ \\
\hline Dressed weight (g) & $916.67^{a}$ & $846^{\mathrm{b}}$ & $669.67^{c}$ & $* *$ \\
\hline Dressing Percentage & $60.10^{\mathrm{a}}$ & $58.50^{b}$ & $57.40^{c}$ & $* *$ \\
\hline
\end{tabular}

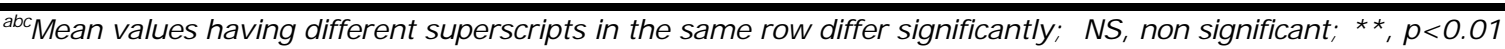

Table 3. Average values for dressing parameters of three genotypes of duck at 150 days of age

\begin{tabular}{lllll}
\hline Parameters & Khaki Campbell & Jinding & Deshi & Level of sig \\
\hline Live weight at slaughter (g) & $1522.50^{\mathrm{a}}$ & $1441.67^{\mathrm{b}}$ & $1155.83^{\mathrm{c}}$ & $* *$ \\
Breast weight (\%) & $18.76^{\mathrm{a}}$ & $18.62^{\mathrm{b}}$ & $17.76^{\mathrm{c}}$ & $* *$ \\
Thigh weight (\%) & $11.37^{\mathrm{a}}$ & $11.33^{\mathrm{ab}}$ & $10.25^{\mathrm{b}}$ & $* *$ \\
Head weight (\%) & $3.37^{\mathrm{a}}$ & $3.29^{\mathrm{b}}$ & $3.27^{\mathrm{c}}$ & $* *$ \\
Neck weight (\%) & 4.82 & 4.76 & 4.75 & $\mathrm{NS}$ \\
Wing weight (\%) & $3.88^{\mathrm{a}}$ & $3.83 \mathrm{~b}$ & $3.76^{\mathrm{c}}$ & $* *$ \\
Leg weight (\%) & $2.16^{\mathrm{a}}$ & $2.09^{\mathrm{b}}$ & $2.04^{\mathrm{b}}$ & $* *$ \\
Shank weight (\%) & $2.26^{\mathrm{a}}$ & $2.25^{\mathrm{a}}$ & $2.13^{\mathrm{b}}$ & $* *$ \\
Drumstick weight (\%) & $12.77^{\mathrm{a}}$ & $11.76^{\mathrm{a}}$ & $12.65^{\mathrm{b}}$ & $* *$ \\
Abdominal fat (\%) & $0.82^{\mathrm{a}}$ & $0.78^{\mathrm{ab}}$ & $0.59^{\mathrm{b}}$ & $* *$ \\
Dressed weight (g) & $918.67^{\mathrm{a}}$ & $846.67^{\mathrm{b}}$ & $668.67^{\mathrm{c}}$ & $* *$ \\
Dressing Percentage & $60.20^{\mathrm{a}}$ & $58.72^{\mathrm{b}}$ & $57.22^{\mathrm{b}}$ & $* *$ \\
\hline
\end{tabular}

${ }^{\mathrm{abc}}$ Means having different superscripts in a row differ significantly; NS, non significant; **, $\mathrm{p}<0.01$ 
The mean values for dressed weight of Khaki Campbell $(918.67 \mathrm{~g})$ were slightly higher than that of Jinding genotypes and the mean values for dressed weight of Jinding genotypes of ducklings were significantly higher than Deshi genotypes but lower than the result found by Khatun (2003). Dressing percentage of showed in table 3, Khaki Cambell $(60.20 \%)$ was higher than that of Jinding and Deshi genotypes. In this study, dressing percentage of Jinding (58.72\%) was higher than the result found by Khatun (2003), and this may be due to the supplementation of feed in addition to scavenging.

\section{Conclusion}

Comparison between two locations, ducks reared in Barisal showed better performance in terms of body weight, growth rate, meat yield charateristics. Khaki Campbell and Jinding ducklings were found almost similar in growth rate and meat yield characteristics. Considering the parameters studied both Khaki Campbell and Jinding ducks may be suggested to rear in the coastal region of Bangladesh.

\section{Acknowledgements}

The fund for the research work was provided by Palli Karma Sahayak Foundation (PKSF) Dhaka. The authors are gratefully acknowledge the receipt of the fund from the organization. The authors are also gratefull to the farmers of Barishal and Bhola Districts who directly involved with the research work.

\section{References}

Ahmed S and Islam N (1985). Backyard Poultry Development Project in 100 villages, sponsored by Bang. Agri. Univ., Mymensing and assisted by UNICEF, Bangladesh. Proc. $1^{\text {st }}$ Conf. Bang. Anim. Husbandry Assoc., Bangladesh Agricultural Research Council, Dhaka. P. 133-138.

Arboleda CR (1990). Development of Duck Industry in Bangladesh. A discussion paper presented to selected government officers, at the Department of Livestock Services, Pashu Sampad Bhaban, Dhaka, October 30.

DLS (2003). Annual Progress Report. Department of Livestock Services. Farm gate, Dhaka.

Farrell DJ and Stapleton P (1986). Duck Production Science and World Practice. The University of New England, Armidale, NSW. P. 430.

Huque KS and Sultana N (2003). Organic Duck farming in Bangladesh and Entrepreneurship Development. Proceeding of $3^{\text {rd }}$ International Poultry Show and Seminar. Bangladesh China Friendship Conference Center, Dhaka, Bangladesh. P. 279-287.

Islam MN, Huque QME, Salah Uddin $M$ and Sarker MSK (2003). Potentiality of Native Genotypes of Ducks. Proceedings of $3^{\text {rd }}$ International Poultry Show and Seminar, Bangladesh China Friendship Conference Center, Dhaka, Bangladesh. P. 259-270.

Khatun $\mathrm{MH}$ (2003). Effect of supplementing rice polish, broken rice or maize on growth performance of finding Ducks under scavenging system. M.S. thesis, Dept. Anim. Nutrition, Bang. Agri. Univ., Mymensingh, Bangladesh.

Singh B, Singh H, Singh CV and Singh B (2003). Genetic parameters of growth, egg production and egg quality traits in WLH. Indian J. Poult. Sci. 35: 3-16. 